Quality Management in ART Clinics 

Fabiola Bento • Sandro Esteves • Ashok Agarwal Editors

\section{Quality Management in ART Clinics}

A Practical Guide

囪 Springer 


\section{Editors}

Fabiola Bento, BBA, MBE

Quality Manager and ISO Quality

Management System Representative

ANDROFERT

Andrology and Human Reproduction Clinic

Campinas, SP, Brazil

Ashok Agarwal, PhD, HCLD (ABB)

Director, Andrology Laboratory and

Reproductive Tissue Bank

Director, Center for Reproductive Medicine

Cleveland Clinic Foundation

Cleveland, OH, USA

\author{
Sandro Esteves, MD, $\mathrm{PhD}$ \\ Director, ANDROFERT \\ Andrology and Human Reproduction Clinic \\ Campinas, SP, Brazil
}

ISBN 978-1-4419-7138-8

ISBN 978-1-4419-7139-5 (eBook)

DOI 10.1007/978-1-4419-7139-5

Springer New York Heidelberg Dordrecht London

Library of Congress Control Number: 2012949556

(C) Springer Science+Business Media New York 2013

This work is subject to copyright. All rights are reserved by the Publisher, whether the whole or part of the material is concerned, specifically the rights of translation, reprinting, reuse of illustrations, recitation, broadcasting, reproduction on microfilms or in any other physical way, and transmission or information storage and retrieval, electronic adaptation, computer software, or by similar or dissimilar methodology now known or hereafter developed. Exempted from this legal reservation are brief excerpts in connection with reviews or scholarly analysis or material supplied specifically for the purpose of being entered and executed on a computer system, for exclusive use by the purchaser of the work. Duplication of this publication or parts thereof is permitted only under the provisions of the Copyright Law of the Publisher's location, in its current version, and permission for use must always be obtained from Springer. Permissions for use may be obtained through RightsLink at the Copyright Clearance Center. Violations are liable to prosecution under the respective Copyright Law.

The use of general descriptive names, registered names, trademarks, service marks, etc. in this publication does not imply, even in the absence of a specific statement, that such names are exempt from the relevant protective laws and regulations and therefore free for general use.

While the advice and information in this book are believed to be true and accurate at the date of publication, neither the authors nor the editors nor the publisher can accept any legal responsibility for any errors or omissions that may be made. The publisher makes no warranty, express or implied, with respect to the material contained herein.

Printed on acid-free paper

Springer is part of Springer Science+Business Media (www.springer.com) 


\section{Foreword}

This is no ordinary book. It is a detailed description, such as has never before compiled, of the current status of quality management in centers specialized in assisted reproductive technology (ART). It describes in detail the various items of equipment and supplies necessary to set up the laboratory procedures used in the treatment of male and female infertility. This work aims at providing invaluable information on how to set up, organize, manage, and improve an already existing assisted reproduction laboratory. The work approaches several aspects of the procedures involved in running reproductive medicine centers: from the management of systems to appropriately training personnel, to orchestrating top quality control, and finally to deliver outstanding quality assurance. It is gratifying to see that this work is grounded in the belief that the key to running a service is understanding customer satisfaction, the regulations, selecting the appropriate and preparing the appropriate individuals, and picking the ideal management procedures.

Since the first success of IVF in 1978, the field has been transformed by a steady stream of discovery and technological progress. This has led to the expansion of the indications such as diagnosis and treatment of severe male infertility treated by ICSI and the identification and eradication of genetic disorders by PGD, not to mention the improvement of ART successes by the introduction of sophisticated and comprehensive chromosomal screening. These discoveries and techniques are grouped under the term assisted reproduction techniques. For the first time, this book describes in a clear and concise manner the "how, why, and therefore" of such procedures. It has been written to be readable and usable by research fellows, embryologists, and technicians who need some insight into the management implementation, and who wish to know the $\mathrm{A}-\mathrm{Z}$ of how to run and manage a reproductive laboratory as seen and performed by the three distinguished authors.

It is always exciting to browse through a new book, particularly a manual, but as we go along, we often notice that the information is too polished, presented from an ideal standpoint and often dealing with theoretical situations. Such material makes a good book but from a practical point of view often may not prove to be very useful. The authors could have been trapped by the irresistible drive to be too comprehensive and make a thick book that would have lost practical usefulness and contact 
with the reality of our times in terms of proficiency testing requirements and regulations.

Instead, Drs. Agarwal, Bento, and Esteves provide breadth and depth on topics related to research, management, and clinical fields. Collectively, they have produced a work that stays on track and provides essential advice to serve researchers, clinicians, and laboratory staff. The authors deliver a quick, practical, troubleshooting manual for the laboratory with an international scope and pedigree. This work will help scientists, embryologists, and technicians feel secure in setting up their systems and dealing with the daily difficulties of a routine. The manual integrates current successful aspects of reproductive clinical practice and introduces innovative facets to these kinds of endeavors. This includes the most relevant experience in this field as it unfolds in the current performance of reproductive laboratories in the United States, Europe, and other reputable representative countries.

In short, the work is dynamic. Those who read it will ultimately be able to better understand and better serve their patients' needs. There is an authoritative exposition of the different steps of ART, ranging from the routine of well-established procedures to the generation of future conduct of practice. This manual represents a milestone in the literature of reproductive medicine and will benefit all who read it. 


\section{Foreword}

Today's world cannot be imagined without assisted reproductive technology (ART), which have been as revolutionary to civilization as modern contraception in the 1960s. After three decades of pioneering discoveries and ongoing developments, assisted reproduction has finally come of age. Quality management has been introduced, many clinics have become certified, and accreditation requirements and national and international regulation have formalized our quality control systems. However, quality management has not only to do with operating procedures, documentation, traceability, and risk minimization but also needs to address safety in the long term. Within the European Society for Human Reproduction and Embryology (ESHRE), a special interest group on "quality and safety in ART" tries to deal with risks and complications in both the short and the long terms. The topics addressed range from ovarian hyperstimulation syndrome and multiple pregnancies to genetic and epigenetic risks in ART offspring. Studying long-term risks is not possible without registration, and registration is impossible without documentation and quality control systems being in place. Quality management therefore is of the utmost importance, not just to please regulatory bodies and authorities in order to get licensed, but because of the safety issues touching the men and women we treat and their children yet to come.

The book you are about to read is in my opinion mandatory lecture for anybody involved in modern assisted reproduction. It should be on the desks in the clinic as well as on the shelves in the lab. It makes it easy to understand the steps to follow in establishing a comprehensive management system and allows the reader to learn from experiences worldwide. Operating in ART is unique because of the necessary integration of clinical, paramedical, laboratory, and administrative activities, making communication between all four groups very important. In this book, you will learn how to deal with setting up quality control systems at all levels and integrating them into one successful unit, where increased patient satisfaction will ultimately 
lead to greater success of the clinic and better quality of care for the couples and children we treat. Whether you are about to start a clinic, have just decided to introduce a formal quality management system, or are a veteran in the field of quality control, you will like this book. It has fulfilled the ambition to be relevant at a truly global level and is a "must read" in our field for years to come.

Ghent, Belgium

Petra De Sutter, M.D., Ph.D. 


\section{Preface}

The objective of this book is to help ART centers comply with the demand to establish a Quality Management System, providing a step-by-step logical sequence to facilitate system implementation. The book covers basic concepts that are part of any model of quality management system chosen and also presents the experience many centers around the world have had in developing and using a quality management system, so as to identify common difficulties, challenges, and successes.

Chapter 1 offers an introduction to quality management in ART clinics. Chapter 2 presents some quality management tools, giving practical examples and explaining how these tools can be used and can help make a quality system work. It will neither focus on a particular tool nor go into extensive details about any of them. The idea is to present readers with what is available and enable them to follow whatever trend they may find suitable for their practices.

Chapter 3 starts with basic concepts to start the process of establishing a quality management system, such as how to define one's mission and quality management policies, how to register and control nonconformities as well as define corrective and preventive actions, and how to use satisfaction questionnaires to set goals and monitor performance.

Chapter 4 focuses on the daily activities of an ART Center, showing ways to have an overview of all activities involved, through flowcharts and interactions, and also showing the importance of standardization to achieve uniformity and guarantee quality. SOP's descriptions, reviews, and controls are also addressed.

Chapter 5 talks about training. The intention is not to present a training program but to suggest training subjects that can be covered for a quality system to be successful. It will also address issues such as internal satisfaction and how to evaluate staff's performance.

Chapter 6 focuses on communication. No quality management system can survive without a proper communication system. It will cover auditing processes, discussion and improvement groups, and the presentation of regular reports and indicators. 
Chapters 7-10 provide an overview of how reproductive laboratories (RL), i.e., andrology and embryology clinical laboratories, can be integrated in a quality management system. These chapters define and explain the three pillars of quality for RLs attempting to operate in a quality management philosophy, i.e., (1) Defining what you do; (2) explaining how you do; and (3) making sure that what you do is being done in the proper manner, and provide tools and practical examples that will aid in the development of a quality management plan for reproductive labs. In Chap. 7 we provide an introduction to the role of reproductive laboratories in ART clinics. In Chap. 8, we present an overview of the scope of activities and services performed by typical clinical reproductive laboratories. Chapter 9 discusses what is needed for RLs to perform the procedures under their scope of activity. The role of laboratory manuals, personnel, structure and resources, and laboratory safety is fully covered. Chapter 10 describes and explains the critical quality activities for clinical reproductive laboratories operating in the context of quality management. Quality control (QC), quality assurance (QA), and quality improvement (QI) as key quality management elements should be fully integrated to not only identifying problems but also finding their solutions as well as ensuring and optimizing the quality of laboratory services.

Chapters 11 through 21 present the experience of ART Centers around the world in the establishment of their own quality management systems. The collaborating efforts of contributors in this section geographically span Europe, Latin America, Australia, Africa, Asia, as well as the USA. The idea is not to say what is right or wrong, but to show what worked and what did not work in different countries. Despite their regional and cultural differences, they do have a lot in common, and what they reported may enlighten those who are struggling to succeed. ART Centers will answer the following questions besides addressing issues that were particularly important in their practices:

- In your country, should ART Center legally comply with official regulations? Is having a Quality Management System mandatory?

- What are the key elements of your countries regulations, if any, regarding quality management?

- Which Quality Management System is in place at your center? Why did you decide to use this system?

- Which were the main challenges your ART Center faced to implement the Quality Management System and how were they overcome?

- What are the key elements of your Center's Quality Management System?

- What was gained by implementing a Quality Management System?

The ART Centers participating in these chapters are distributed around the world so as to show how this issue is dealt with in different countries and cultures (Fig. 1).

Each country follows its own regulation and directives, regardless of their being mandatory or simply a matter of choice (Table 1). It is interesting to note that some countries have to follow more than one guideline while others have no mandatory guidelines at all. 


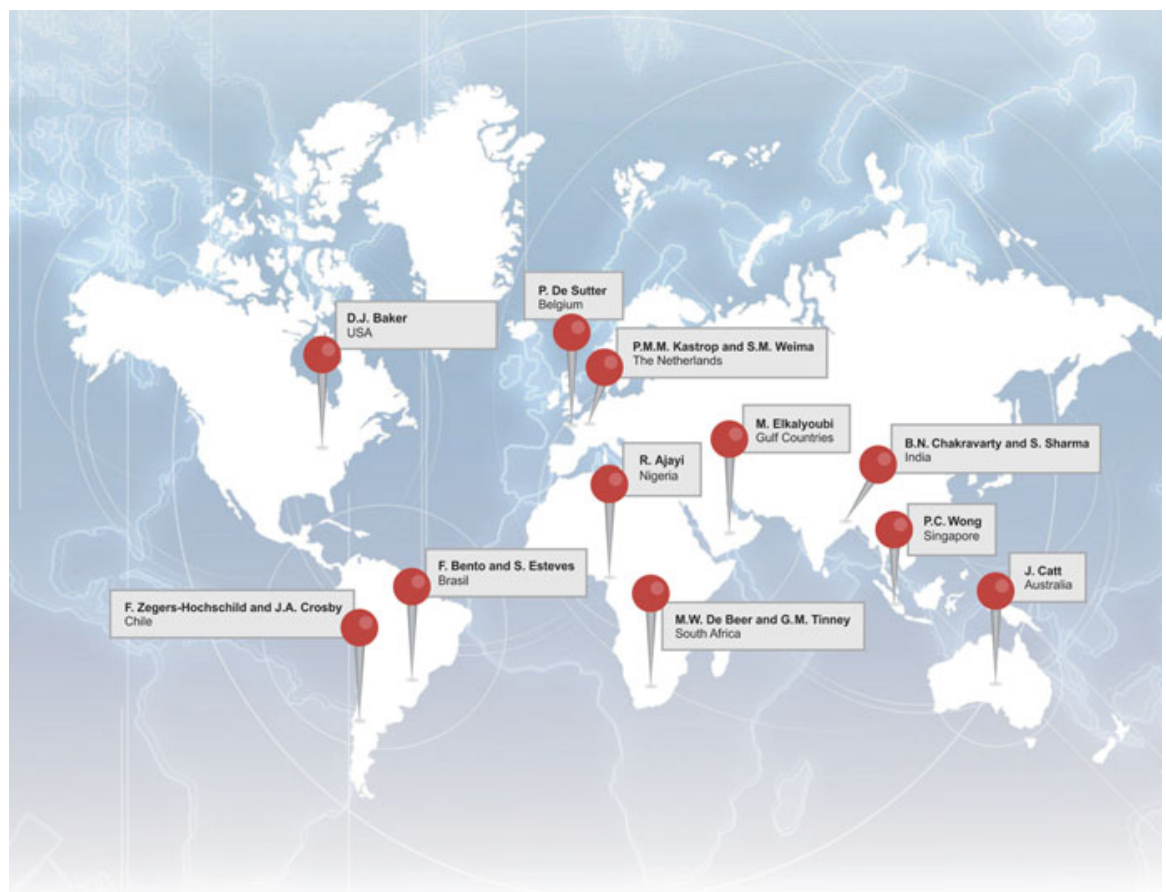

Fig. 1 Authors who contributed with chapters on international experience and their locations

Table 1 International guidelines and directives for ART

\begin{tabular}{lll}
\hline Country & $\begin{array}{l}\text { Official guidelines and } \\
\text { directives-mandatory }\end{array}$ & Other guidelines-non-mandatory \\
\hline Australia & Code of Practice for Assisted & \\
& Reproductive Technology & \\
& Units, RTAC-Reproductive & \\
& Technology Accreditation & \\
& Committee & \\
Belgium & EU Directive 2004/23/EG & ISO 9001:2008 \\
& EU Directive 2006/17/EG & \\
& EU Directive 2006/86/EG & \\
& Belgium Law (BS 30/12/2008) & \\
Brasil & RDC 33, 17/02/06, ANVISA- & ISO 9001:2008 \\
& Agência Nacional de Vigilância & \\
& Sanitária & Guidelines and Regulations \\
& CFM 1957/10, 15/12/10, CFM- & REDLARA-Latin America \\
& Federal Medicine Council & Network of Assisted Reproduction \\
Chile & & Guidelines and Regulations \\
& & REDLARA-Latin America \\
& & Network of Assisted Reproduction \\
\hline
\end{tabular}


Table 1 (continued)

\begin{tabular}{|c|c|c|}
\hline Country & $\begin{array}{l}\text { Official guidelines and } \\
\text { directives }- \text { mandatory }\end{array}$ & Other guidelines-non-mandatory \\
\hline Gulf Countries & & $\begin{array}{l}\text { American Society of Reproduction } \\
\text { Medicine Standards } \\
\text { European Society of Human } \\
\text { Reproduction and Embryology } \\
\text { (ESHRE) Standards } \\
\text { U.S. Department of Health and Human } \\
\text { Services Standards } \\
\text { Australian Council of Healthcare } \\
\text { Standards } \\
\text { International Organization for } \\
\text { Standardization-ISO }\end{array}$ \\
\hline India & & $\begin{array}{l}\text { ICMR - Indian Council of Medical } \\
\text { Research } \\
\text { National Guidelines for Accreditation, } \\
\text { Supervision and Regulation of ART } \\
\text { Clinics in India-2007 }\end{array}$ \\
\hline Nigeria & & $\begin{array}{l}\text { HFEA Code of Practice. 6th edition } \\
\text { ISO 9001:2008 }\end{array}$ \\
\hline Singapore & & $\begin{array}{l}\text { ISO 9001:2008 } \\
\text { Joint Commission Accreditation of } \\
\text { Health Care Organization } \\
\text { (JJCAHCO) - Joint Commission } \\
\text { International (JCI) }\end{array}$ \\
\hline South Africa & $\begin{array}{l}\text { National Health Act (No. } 61 \text { of } \\
\text { 2003, Chapters 1-3) } \\
\text { Human Tissue Act (No. } 65 \text { of 1983) } \\
\text { Children's Act (No. } 38 \text { of 2005) }\end{array}$ & $\begin{array}{l}\text { American Society of Reproduction } \\
\text { Medicine Guidelines and Protocols } \\
\text { HFEA Code of Practice. 6th edition } \\
\text { Standard Guidelines - SASREG (South } \\
\text { African Society of Reproductive } \\
\text { Medicine and Gynecological } \\
\text { Endoscopy }\end{array}$ \\
\hline The Netherlands & $\begin{array}{l}\text { GMP: Good Manufacturing Practice, } \\
\text { Dutch Government } \\
\text { EU Directive 2004/23/EC, } \\
\text { Ministry of Health, Welfare and } \\
\text { Sports } \\
\text { Artificial Insemination donor } \\
\text { information Act } \\
\text { Embryo Act } \\
\text { Safety and Quality of Body } \\
\text { Materials Act } \\
\text { Requirements for Body Materials } \\
\text { Decree }\end{array}$ & $\begin{array}{l}\text { CCKL Code of Practice } \\
\text { ISO 15189:2003 }\end{array}$ \\
\hline The USA & $\begin{array}{l}\text { CLIA for Andrology Laboratories } \\
\text { FDA for Cryobiology }\end{array}$ & CAP Accreditation \\
\hline
\end{tabular}


Based on this information, we have tried to gather a heterogeneous group to show how a Quality Management System has been applied in different settings. Despite all differences, similar experiences and difficulties are noticed, and much can be learned from this group. Their experience can help both those who already have a system in place, and sometimes struggle to keep it working, and those who are implementing a brand new Quality Management System.

Campinas, SP, Brazil

Campinas, SP, Brazil

Cleveland, OH, USA
Fabiola Bento, B.B.A., M.B.E. Sandro Esteves, M.D., Ph.D. Ashok Agarwal, Ph.D., H.C.L.D. (A.B.B.) 



\section{Contents}

\section{Part I Establishing a Quality Management System}

1 Introduction to Quality Management in ART Clinics ....................... 3

Fabiola Bento, Sandro Esteves, and Ashok Agarwal

2 Quality Management Systems ........................................................ 7

Silveraldo Mendes

3 Where to Start

Fabiola Bento

4 Defining Processes and Procedures .................................................. 39

Fabiola Bento

5 Training Personnel ........................................................................... 49

Fabiola Bento

6 How To Get Information ................................................................. 59

Fabiola Bento

\section{Part II Reproductive Laboratories}

7 The Role of Reproductive Laboratories in the ART Clinic............... 71 Sandro Esteves and Ashok Agarwal

8 Defining What Reproductive Laboratories Do ............................... 75 Sandro Esteves and Ashok Agarwal

9 Explaining How Reproductive Laboratories Work.......................... 79 Sandro Esteves and Ashok Agarwal

10 Ensuring that Reproductive Laboratories Provide High-Quality Services

Sandro Esteves and Ashok Agarwal 


\section{Part III International Experience}

11 Singapore

P.C. Wong

12 India

B.N. Chakravarty and S. Sharma

13 South Africa: A Laboratory Perspective on Quality Control

Marie-Lena Windt de Beer and Gregory Michael Tinney

14 Nigeria: Experience with Quality Management and IVF in a Developing Country

Richard Ajayi

15 Gulf Countries

Mohamed Elkalyoubi

16 United States of America

Doris J. Baker

17 Chile 203

Fernando Zegers-Hochschild and Javier A. Crosby

18 Brazil 209

Fabiola Bento and Sandro Esteves

19 Belgium: ISO 9001:2000 Certification as a Base

for Total Quality Management in ART

Kelly Tilleman, Etienne Van den Abbeel, Ilse De Croo,

Anneleen Van de Velde, Bjorn Heindryckx, Sandra Deltombe,

Isabelle Stuyver, Annick Geril, and Petra De Sutter

20 The Netherlands

Peter M.M. Kastrop and Sjerp M. Weima

21 Australia: QMS in IVF Centres James Catt

Index 239 


\section{Contributors}

Etienne Van den Abbeel, Ph.D. Department of Reproductive Medicine, University Hospital Ghent, Ghent, Belgium

Ashok Agarwal, Ph.D., H.C.L.D. (A.B.B.) Andrology Laboratory and Reproductive Tissue Bank, Center for Reproductive Medicine, Cleveland Clinic Foundation, Cleveland, $\mathrm{OH}$, USA

Richard Ajayi, F.R.C.O.G. Department of Clinicals and Management, The Bridge Clinics, Lagos, Nigeria

Doris J. Baker, Ph.D., M.S., B.S. Division of Clinical Sciences, University of Kentucky, Lexington, KY, USA

Fabiola Bento, B.B.A., M.B.E., ANDROFERT, Andrology and Human Reproduction Clinic, Campinas, SP, Brazil

James Catt, Ph.D. Optimal IVF, Melbourne, VIC, Australia

B.N. Chakravarty, M.D., F.R.C.O.G. Institute of Reproductive Medicine, Kolkata, India

Javier A. Crosby, Ph.D. Unidad de Medicina Reproductiva, Clínica Las Condes, Santiago, Chile

Ilse De Croo Department of Reproductive Medicine, University Hospital Ghent, Ghent, Belgium

Petra De Sutter, Ph.D., M.D. Department of Reproductive Medicine, University Hospital Ghent, Ghent, Belgium

Sandra Deltombe Department of Reproductive Medicine, University Hospital Ghent, Ghent, Belgium 
Mohamed Elkalyoubi, M.B.B.Ch., M.Sc., Dip. Gyn. Endocscopy, F.R.C.O.G. Dubai Gynaecology and Fertility Center, Dubai Health Authority, Dubai, United Arab Emirates

Sandro Esteves, M.D., Ph.D. ANDROFERT, Andrology and Human Reproduction Clinic, Campinas, SP, Brazil

Annick Geril Department of Reproductive Medicine, University Hospital Ghent, Ghent, Belgium

Bjorn Heindryckx, Ph.D. Department of Reproductive Medicine, University Hospital Ghent, Ghent, Belgium

Peter M.M. Kastrop, Ph.D. Department of Reproductive Medicine and Gynaelcologie, University Medical Center Utrecht, Utrecht, The Netherlands

Silveraldo Mendes, M.A. Process and Member Services Department, GS1 Brazil Brazilian Association Automation, São Paulo, Brazil

S. Sharma, M.D., F.N.B. Institute of Reproductive Medicine, Kolkata, India

Isabelle Stuyver Department of Reproductive Medicine, University Hospital Ghent, Ghent, Belgium

Kelly Tilleman, Ph.D. Department for Reproductive Medicine, University Hospital Ghent, Ghent, Belgium

Gregory Michael Tinney, B.S., M.Sc. Aevitas Fertility Clinic, Vincent Pallotti Hospital, Cape Town, South Africa

Anneleen Van de Velde Department of Reproductive Medicine, University Hospital Ghent, Ghent, Belgium

Sjerp M. Weima, Ph.D. Fertility Laboratory, Department of Reproductive Medicine and Gynaelcologie, University Medical Center Utrecht, Utrecht, The Netherlands

Marie-Lena Windt de Beer, Ph.D. Department of Obstetrics and Gynaecology [Fertility Clinic], Tygerberg Hospital, Tygerberg, South Africa

Aevitas Fertility Clinic, Vincent Pallotti Hospital, Tygerberg, South Africa

P.C. Wong, F.R.C.O.G. Department of Obstetrics and Gynaecology, National University Hospital, Singapore, Singapore

Fernando Zegers-Hochschild, M.D. Unidad de Medicina Reproductiva, Clínica Las Condes, Santiago, Chile 